НІКІШИНА О.В.

д-р екон. наук, ст.наук.співроб.

відділу ринкових механізмів та структур

Інститут проблем ринку та економіко- екологічних досліджень НАНУ

Франиузький б-р, 29 м. Одеса, Україна, 65044

E-mail: ksenkych@gmail.com

ORCID: 0000-0002-7172-3551

\title{
ЛОЗОВА Т.П.
}

Молодший науковий співробітник

відділу ринкових механізмів та структур

Інститут проблем ринку та економіко-екологічних досліджень НАНУ

Французький б-р, 29 м. Одеса, Україна, 65044

E-mail:ua.lozovaya@gmail.com

ORCID: 0000-0002-4896-1930

\section{ФОРМУВАННЯ ЕФЕКТИВНИХ КООПЕРАТИВНИХ ЛАНЦЮГІВ ВАРТОСТІ НА АГРОПРОДОВОЛЬЧИХ РИНКАХ УКРАЇНИ}

Актуальність. В умовах посилення конкуренції на світових ринках та домінування корпоративних ланцюгів вартості виникає необхідність у впровадженні кооперативної моделі взаємодії малих товаровиробників. В Україні формування кооперативних ланцюгів вартості має пріоритетне значення на агропродовольчих ринках, розвиток яких базується на консолідаџії ресурсів та паритетних взаємодіях суб'єктів індивідуального та корпоративного секторів. Розбудова кооперативних ланиюгів вартості дозволить підвищити конкурентоспроможність дрібних агровиробників, що актуалізує необхідність нових досліджень у даному напрямі.

Мета та завдання. Мета статті - розробка науково-прикладних засад формування та регулювання кооперативних ланцюгів вартості на агропродовольчих ринках Украӥни на основі відтворювального підходу. Основні завдання дослідження: встановити соціально-економічні передумови аграрної кооперації в Україні; визначити сучасні тендениії та функиії сільськогосподарських кооперативів у розвитку аграрного сектору економіки; обтрунтувати структуру ефективного кооперативного ланцюга вартості та стимулюючі заходи держави. Методи дослідження: системний підхід, аналітичних узагальнень, структурний, індексний, порівняльний, графічний.

Результати. Розглянуто основні проблеми доступу дрібних агровиробників до корпоративних ринкових ланцюгів, встановлено логістичну відторгненість суб'єктів індивідуального сектору від прибуткових ланок доробки й розподілу продукиї. На основі емпіричних досліджень визначено домінуючий напрям перерозподілу доданої вартості у ланцюгах ринку на користь великих корпорацій та посередників. Авторами обтрунтовано кооперативну модель формування ефективних ланцюгів агропродовольчого ринку, які включають багатофункціональні кооперативи, логістичний центр та магазини роздрібної торгівлі.

Висновки. Запропоновано комплекс заходів державної підтримки створення та розвитку кооперативних ланц̧югів вартості на агропродовольчих ринках України. Впровадження даних заходів орієнтовано на забезпечення конкурентоспроможності кооперативних ланиюгів ринку та їх здатності взаємодіяти на паритетних засадах із ланцюгами корпоративного та посередницького типу. Наукова новизна дослідження полягає в обтрунтуванні науково-прикладних засад формування ефективних кооперативних ланџюгів для більш об'єктивного перерозподілу доданої вартості між суб 'єктами таких ланцюгів, подолання структурних і иінових дисбалансів агропродовольчого ринку для його відтворювального розвитку.

Ключові слова: ланцюги вартості, кооперачія, агропродовольчий ринок, багатофункціональні кооперативи, індивідуальні товаровиробники, додана вартість.

NIKISHYNA O.V.

Doctor of Economic Sciences, Senior Researcher,

Head of Department of market mechanisms and structures,

Institute of Market Problems and Economic\&Ecological Research

of the National Academy of Sciences of Ukraine

Odessa, Ukraine

E-mail: ksenkych@gmail.com 
LOZOVA T.P.

Junior research employee

Department of market mechanisms and structures

Institute of Market Problems and Economic\&Ecological Research

of the National Academy of Sciences of Ukraine

Odessa, Ukraine

E-mail: ua.lozovaya@gmail.com

ORCID: 0000-0002-4896-1930

\section{FORMATION OF EFFECTIVE COOPERATIVE VALUE CHAINS ON AGRICULTURAL FOOD MARKETS OF UKRAINE}

Topicality. With increasing competition in world markets and the dominance of corporate value chains, there is a need to introduce a cooperative model of interaction of small producers. In Ukraine, the formation of cooperative value chains is a priority in agri-food markets, the development of which is based on the consolidation of resources and parity of entities of the individual and corporate sectors. The development of cooperative value chains will increase the competitiveness of small agricultural producers, which highlights the need for new research in this area.

Aim and tasks. The purpose of the article is to develop scientific and applied principles of formation and regulation of cooperative value chains in the agri-food markets of Ukraine on the basis of a reproductive approach. The main objectives of the study: to establish the socio-economic preconditions of agrarian cooperation in Ukraine; identify current trends and functions of agricultural cooperatives in the development of the agricultural sector of the economy; substantiate the structure of an effective cooperative value chain and incentives for the state. Research methods: system approach, analytical generalizations, structural, index, comparative, graphic.

Research results. The main problems of access of small agricultural producers to corporate market chains are considered, the logistical detachment of the subjects of the individual sector from the profitable links of finishing and distribution of products is established. Based on empirical research, the dominant direction of redistribution of value added in market chains in favor of large corporations and intermediaries has been determined. The authors substantiate the cooperative model of forming effective chains of the agri-food market, which include multifunctional cooperatives, a logistics center and retail stores.

Conclusion. A set of measures of state support for the creation and development of cooperative value chains in the agri-food markets of Ukraine is proposed. The implementation of these measures is focused on ensuring the competitiveness of cooperative market chains and their ability to interact on a parity basis with corporate and intermediary chains. The scientific novelty of the study is to substantiate the scientific and applied principles of forming effective cooperative chains for a more objective redistribution of value added between the subjects of such chains, overcoming structural and price imbalances of the agri-food market for its reproductive development.

Keywords: value chains, cooperation, agri-food market, multifunctional cooperatives, individual producers, value added.

Problem statement and its connection with important scientific and practical tasks. The formation and development of agricultural cooperation is an important tool to ensure access of individual farms to market infrastructure, increase the efficiency of their activities by objective redistribution of value added in the cooperative chain, overcoming structural and price imbalances in the agricultural market. At the same time, the formation of agrarian cooperatives is a mechanism of self-organization of the rural population, increasing their employment and welfare, sustainable development of rural areas. In Ukraine, agrarian cooperation, despite the strong potential of the individual market sector, has not been sufficiently developed. Possibilities of agrarian cooperatives, in particular multifunctional ones, allow to form a network of effective cooperative market chains, able to compete with corporate value chains, which actualizes scientific and applied research in this direction.

Analysis of recent publications on the problem. Theoretical and methodological foundations of the formation of value chains at the micro and macro levels are reflected in the works of many domestic and foreign scientists, in particular, B. Burkinsky [1], O. Borodina [2], M. Kiselski [3], H.-M. Winkels [4], O. Wieliczko, N. Chukhrai, O. Girna, M. Tarakanov and others. Theoretical and applied bases of creation of agrarian cooperatives, problems of their development in Ukraine and international experience of cooperation are thoroughly researched by M. Malik, Yu. Luzan [5], O. Sakovskaya [6], V. Sheremet [7]; issues of greening the agri-food sector and the formation of organic cooperatives - N. Andreeva [8], O. Hetman [9], 
L. Marmul, N. Novak, G. Tyutyunnyk and other scientists. The authors of the article also joined this area of research $[10,11]$.

Allocation of previously unsolved parts of the general problem. Despite the significant number of publications in the field of agricultural cooperation, the issues of creating effective logistics chains of commodity markets in the context of reproductive development of the national economy, the formation of market value chains of cooperative type, models of development of cooperative value chains and their interactions with corporate and corporate chains. and measures to stimulate the cooperative movement in rural areas for their balanced development.

Formulation of research objectives (problem statement). Objectives of the article is to develop scientific and applied principles of formation and regulation of cooperative value chains in the agri-food markets of Ukraine on the basis of a reproductive approach. The study used a systematic approach and general scientific methods, in particular, analytical generalizations - to establish the dominant direction of value added migration in the chains of the agri-food market; structural - to determine the shares of the individual and corporate sectors of the market, the species structure of cooperatives; index - for price analysis; comparative - to compare the levels of profitability of different categories of producers; graphic to visualize the structure of market value chains.

An outline of the main results and their justification. In modern conditions, the key problem in the development of individual agricultural producers (personal farms and farms) is their limited access to market infrastructure. The profitable link of distribution and sale of products is controlled by large corporations and intermediaries, which create barriers for individual producers to access this link, unequal conditions of cooperation, and so on. Under such conditions, small and medium-sized farms are constantly losing added value, which should become a resource for their reproductive development.

In the corporate chains of the agricultural market there is a redistribution of value added in favor of large corporations. This statement is proved by the redistribution of commodity niches of the agrarian market formed in Ukraine by two categories of producers: corporate and individual sector (Table 1). In 2019, the corporate sector produced $65,4 \%$ of cereals, $74,3 \%$ of sunflower, $81,3 \%$ of sugar beets and $65,3 \%$ of meat in Ukraine. At the same time, households produced $98,2 \%$ of potatoes, $85,3 \%$ and $83,4 \%$ of vegetables and fruits and berries, respectively, and $71,5 \%$ of milk. Farms occupy certain niches in the production of agricultural products. The formed subjective structure of agricultural production is a consequence of the economic dominance of the corporate sector and the dependent position of individual farms.

Table 1

Shares of corporate and individual sectors in the production of agricultural products in Ukraine, \%*

\begin{tabular}{|c|c|c|c|c|c|c|c|c|c|}
\hline \multirow{4}{*}{ Types of goods } & \multirow{2}{*}{\multicolumn{3}{|c|}{ Corporate sector }} & \multicolumn{6}{|c|}{ Individual sector } \\
\hline & & & & \multicolumn{3}{|c|}{ Farms } & \multicolumn{3}{|c|}{ Households } \\
\hline & \multicolumn{9}{|c|}{ Years } \\
\hline & 2005 & 2010 & 2019 & 2005 & 2010 & 2019 & 2005 & 2010 & 2019 \\
\hline 1. Cereals & 65,0 & 63,9 & 65,4 & 10,7 & 12,0 & 14,4 & 24,3 & 24,2 & 20,2 \\
\hline 2. Sunflower & 63,2 & 64,7 & 74,3 & 15,6 & 17,8 & 20,3 & 21,2 & 17,5 & 5,4 \\
\hline 3. Sugar beet & 69,6 & 83,7 & 81,3 & 8,9 & 8,4 & 4,5 & 21,5 & 7,9 & 14,2 \\
\hline 4. Potatoes & 0,8 & 1,7 & 1,3 & 0,4 & 0,9 & 0,5 & 98,8 & 97,4 & 98,2 \\
\hline 5. Vegetable crops & 8,6 & 9,3 & 11,7 & 2,1 & 2,6 & 3,0 & 96,3 & 88,1 & 85,3 \\
\hline 6. Fruit and berry crops & 11,8 & 16,4 & 11,9 & 0,0 & 0,0 & 4,7 & 88,2 & 83,6 & 83,4 \\
\hline 7. Meat of all kinds & 35,9 & 52,8 & 65,3 & 0,9 & 2,3 & 2,8 & 63,2 & 44,9 & 31,9 \\
\hline 8. Milk of all kinds & 18,1 & 18,7 & 26,0 & 0,7 & 1,0 & 2,2 & 81,2 & 80,3 & 71,8 \\
\hline
\end{tabular}

*Authors' calculations using data from the State Statistics Service of Ukraine [12, 13].

Comparative analysis of the levels of profitability of goods in terms of different sectors of the agricultural market allows to determine the dominant direction of the distribution of value added. In 2019, the highest level of profitability was in sunflower $(23,5 \%)$, which is grown by the corporate sector. The level of profitability of goods, the production of which is concentrated in the individual sector, is much lower and is 2,8\% for vegetables, 6,2\% for fruit and berry crops (Table 2). In 2019, there is a positive trend of increasing profitability of potatoes and milk (by 8.6\% and 4.5\%) compared to 2018. In general, in 20102017, the highest level of profitability was grain, sunflower and sugar beet; the decrease in its level in 2018- 
2019 is due, in particular, to the «shadowing» of the market. Therefore, the amount of profit as a component of value added created in the corporate sector is at least twice its value in the individual sector

Table 2

Dynamics of levels of product profitability in agricultural enterprises of Ukraine, $\% *$

\begin{tabular}{|l|c|c|c|c|c|c|c|c|}
\hline \multirow{2}{*}{ Cargo } & \multicolumn{7}{|c|}{ Years } & \multirow{2}{*}{$\begin{array}{c}\text { Deviation } \\
(8-7)\end{array}$} \\
\cline { 2 - 10 } & $\mathbf{2 0 0 5}$ & $\mathbf{2 0 1 0}$ & $\mathbf{2 0 1 5}$ & $\mathbf{2 0 1 6}$ & $\mathbf{2 0 1 7}$ & $\mathbf{2 0 1 8}$ & $\mathbf{2 0 1 9}$ & \\
\hline 1. Cereals & 3,1 & 13,9 & 42,6 & 37,8 & 25,0 & 24,7 & 11,8 & $-12,9$ \\
\hline 2. Sunflower & 24,3 & 64,7 & 78,4 & 61,9 & 41,3 & 32,5 & 23,5 & $-9,0$ \\
\hline 3. Sugar beet & 4,8 & 16,7 & 27,7 & 24,6 & 12,4 & $-11,4$ & $-15,4$ & $-4,0$ \\
\hline 4. Potatoes & 16,1 & 23,5 & 24,6 & 0,6 & 10,0 & 6,8 & 15,4 & $+8,6$ \\
\hline 5. Vegetable crops & 17,8 & 62,1 & 32,0 & 15,3 & 9,9 & 13,3 & 2,8 & $-10,5$ \\
\hline 6. Fruit and berry crops & 12,7 & 14,9 & 58,3 & 25,0 & 35,4 & 6,4 & 6,2 & $-0,2$ \\
\hline 7. Milk & 12,2 & 17,9 & 12,7 & 18,6 & 26,9 & 16,1 & 20,6 & $+4,5$ \\
\hline 8. Meat: cattle & $-25,0$ & $-35,9$ & $-16,9$ & $-23,2$ & 3,4 & $-17,7$ & $-27,1$ & $-9,4$ \\
\hline pork & 14,9 & $-7,8$ & 12,6 & $-4,1$ & 3,5 & 6,9 & 4,7 & $-2,2$ \\
\hline poultry & 24,9 & $-4,4$ & $-5,4$ & 3,4 & 7,0 & 5,7 & $-3,7$ & $-9,4$ \\
\hline
\end{tabular}

*Authors' calculations using data from the State Statistics Service of Ukraine [12, 13].

Given the lack of statistical data on the profitability of private farms, to assess the state of their profitability, we will conduct a comparative analysis of levels and price indices of agricultural enterprises and households (Table 3). Calculations indicate lower prices of private farms in market niches controlled by the corporate sector, and vice versa. The exception is milk, the price of which in private farms is about $19 \%$ lower than the prices of agricultural products.

Table 3

The ratio of prices for agricultural products of personal farms to the prices of agricultural enterprises, \%

\begin{tabular}{|l|c|c|c|c|c|c|}
\hline \multirow{2}{*}{ Cargo } & \multicolumn{7}{c|}{ Years } \\
\cline { 2 - 7 } & $\mathbf{2 0 1 0}$ & $\mathbf{2 0 1 5}$ & $\mathbf{2 0 1 6}$ & $\mathbf{2 0 1 7}$ & $\mathbf{2 0 1 8}$ & $\mathbf{2 0 1 9}$ \\
\hline 1. Cereals & 106,7 & 96,3 & 89,6 & 91,0 & 92,4 & 95,7 \\
\hline 2. Oil crops & 102,8 & 89,1 & 90,5 & 88,2 & 87,7 & 81,0 \\
\hline 3. Sugar beet & 74,1 & 80,1 & 102,5 & 90,6 & 93,5 & 92,9 \\
\hline 4. Potatoes & 169,0 & 146,4 & 141,8 & 137,5 & 95,1 & 169,4 \\
\hline 5. Vegetable crops & 120,0 & 193,6 & 148,9 & 167,1 & 180,2 & 259,7 \\
\hline 6. Fruit and berry crops & 208,4 & 166,1 & 225,3 & 151,2 & 180,4 & 279,1 \\
\hline 7. Farm animals (live weight) & 119,8 & 115,4 & 162,6 & 105,5 & 113,9 & 117,6 \\
\hline 8. Milk & 87,2 & 83,3 & 79,7 & 76,7 & 78,9 & 81,0 \\
\hline
\end{tabular}

*Authors' calculations using data from the State Statistics Service of Ukraine [12, 13].

In Ukraine, the connection of individual agricultural producers with the trade sector was very weak, their products are being actively replaced by imported goods. The consumer link of the agri-food chain is controlled mainly by organized retail chains, which set strict standards for goods, control their compliance with consumer requirements. Such rules are too difficult for small agricultural producers to enforce, which generates significant barriers to their participation in the profitable chain of product sales [2, p. 77].

On the other hand, the rejection of the individual sector from interactions with other parts of the agrifood chain leads to a decrease in quality parameters of agricultural products, increasing its losses during storage in unadapted warehouses, which certainly reduces potential profits and value added of small and medium farms. Thus, the minimization of their use of certified seeds, fertilizers, plant protection products is the reason for the lower level of yield of private farms crops compared to large agricultural enterprises, as evidenced by the results of calculations (Table 4).

In particular, in 2019 the level of grain yield in private farms was lower than the same indicator for agricultural enterprises by $31,5 \%$, sunflower seeds - by $27,4 \%$, potatoes - by $33,2 \%$, vegetable crops - by $52,5 \%$. Only in the segment of fruit and berry crops the yield of households is $64,5 \%$ higher than the level of the indicator for agricultural enterprises (Table 4). 
Table 4

The ratio of crop yields of private farms to crop yields of agricultural enterprises in Ukraine, \%

\begin{tabular}{|l|c|c|c|c|c|c|c|}
\hline \multirow{2}{*}{ Cargo } & \multicolumn{7}{|c|}{ Years } \\
\cline { 2 - 8 } & $\mathbf{2 0 0 5}$ & $\mathbf{2 0 1 0}$ & $\mathbf{2 0 1 5}$ & $\mathbf{2 0 1 6}$ & $\mathbf{2 0 1 7}$ & $\mathbf{2 0 1 8}$ & $\mathbf{2 0 1 9}$ \\
\hline 1. Cereals & 101,9 & 90,6 & 77,4 & 71,4 & 75,9 & 65,9 & 68,5 \\
\hline 2. Sugar beet & 88,0 & 91,4 & 72,6 & 64,6 & 69,3 & 69,8 & 72,9 \\
\hline 3. Sunflower & 98,4 & 85,1 & 70,0 & 73,2 & 71,4 & 74,7 & 72,6 \\
\hline 4. Potatoes & 86,7 & 77,0 & 81,0 & 77,8 & 70,0 & 67,2 & 66,8 \\
\hline 5. Vegetable crops & 101,9 & 82,1 & 53,0 & 51,2 & 43,9 & 46,3 & 47,5 \\
\hline 6. Fruit and berry crops & в 6,6p. & в2,6 p. & 166,4 & 154,8 & 179,4 & 128,4 & 164,5 \\
\hline
\end{tabular}

*Authors' calculations using data from the State Statistics Service of Ukraine $[12,13]$.

The analysis revealed a tendency to significantly exceed the growth rate of crop yields in the corporate market sector compared to the individual. Thus, in 2019, compared to 2005, the yield of grain in agricultural enterprises increased 2,1 times, sunflower $-2,1$ times, vegetable crops -2.7 times; growth rates for private farms amounted to, respectively, 1.4, 1.6, 1.3 points [12]. The use of innovative technologies and mineral fertilizers provide corporate structures with high profits against the background of increasing the destructive impact of their activities on the environment and reducing jobs in rural areas. Therefore, the activities of the corporate sector of the market have a negative impact on the sustainable development of rural areas.

In conditions of unequal economic relations, the subjects of the individual sector of the agricultural market remain excluded from the profitable sales channels, and their integration into the corporate chains of the agricultural market is invariably accompanied by a loss of added value. The main way to overcome this problem is to create cooperative market chains in Ukraine that can compete with corporate value chains [14, p. 51].

Agricultural cooperatives are the most common form of cooperative activity in the world. European countries sell more than $60 \%$ of all products produced by farmers through cooperatives in the agricultural sector, Scandinavian - more than $80 \%$; cooperatives in China and Japan sell more than $90 \%$ of agricultural products [15]. Thus, in most developed countries, cooperative chains operate effectively, which not only solve global food problems, but also ensure a high level of competitiveness of individual producers by including them in the cooperative market chain and objective redistribution of value added [14, p. 52].

As of the beginning of 2020, there were 28,07 thousand cooperatives in Ukraine, of which $69,6 \%$ were service cooperatives, $7,9 \%$ - production and $11,7 \%$ - other cooperatives [24]. Service cooperatives are created not for direct production, but for its promotion from the production to the consumer link of the market chain and the provision of various services. By merging into service cooperatives, small and mediumsized businesses seek to gain access to profitable links in the chain, new market niches, fair prices, free themselves from the market power of traders and intermediaries, and so on. The dominance of the service type in the general structure of cooperatives can be assessed as a mechanism of adaptation of entities to market conditions.

The share of agricultural cooperatives is relatively low and in 2020 is 3,6\% for production and 4,5\% for service cooperatives (Table 5). During the period 2012-2020, the share of agricultural production cooperatives decreased by $0,8 \%$, the share of service, by contrast, increased by $4,5 \%$. The vector of structural changes coincides with the direction of dynamic changes: in 2020, compared to 2012, the number of production cooperatives in the agricultural sector decreased by $19,2 \%$, while the number of service cooperatives increased by $42,7 \%$.

Table 5

Dynamics and structure of agrarian cooperatives in Ukraine, units

\begin{tabular}{|c|c|c|c|c|c|c|c|c|}
\hline \multirow{2}{*}{ Cooperatives } & \multicolumn{7}{|c|}{ Years } & \multirow{2}{*}{$\begin{array}{l}\text { Growth } \\
\text { rate, \% }\end{array}$} \\
\hline & 2012 & 2015 & 2016 & 2017 & 2018 & 2019 & 2020 & \\
\hline 1. Production & 1249 & 1009 & 998 & 997 & 996 & 1005 & 1009 & 80,8 \\
\hline $\begin{array}{l}\text { \% to the total number of } \\
\text { cooperatives }\end{array}$ & 4,4 & 4,1 & 3,9 & 3,8 & 3,7 & 3,7 & 3,6 & $X$ \\
\hline 2. Service & 890 & 899 & 949 & 1017 & 1073 & 1207 & 1270 & 142,7 \\
\hline $\begin{array}{l}\text { \% to the total number of } \\
\text { cooperatives }\end{array}$ & 3,1 & 3,6 & 3,7 & 3,8 & 4,0 & 4,4 & 4,5 & $X$ \\
\hline
\end{tabular}

*Authors' calculations using data from the State Statistics Service of Ukraine [12, 13]. 
Awareness of the potential of service cooperation by the subjects of the individual sector of the agricultural market intensified its processes in Ukraine. Thus, compared to January 1, 2018, the number of existing service cooperatives increased by 20,5\% and amounted to 735 units in 2019 (Table 6). In 2019, the largest increase was in fruit and vegetable and dairy cooperatives (by $43 \%$ and $31 \%$, respectively), the smallest - in grain $(2,5 \%)$. The structure of existing service cooperatives is dominated by dairy cooperatives, land cultivation and other services $(25,3 \%, 22 \%$ and $26,9 \%$, respectively). The smallest share is occupied by meat cooperatives $(4,8 \%)$, their number in Ukraine is rapidly declining (by $31,4 \%$ ).

Dynamics and species structure of existing agricultural service cooperatives in Ukraine

Table 6

\begin{tabular}{|l|c|c|c|c|c|c|}
\hline \multirow{2}{*}{ Types of service cooperatives } & \multicolumn{2}{|c|}{$\mathbf{2 0 1 8} * *$} & \multicolumn{2}{c|}{$\mathbf{2 0 1 9} * * *$} & \multicolumn{2}{c|}{ Changes $(+,-)$} \\
\cline { 2 - 7 } & Units & $\%$ & Units & $\%$ & Units & $\%$ \\
\hline Total, including: & $\mathbf{6 1 0}$ & $\mathbf{1 0 0 . 0}$ & $\mathbf{7 3 5}$ & $\mathbf{1 0 0 . 0}$ & $\mathbf{+ 1 2 5}$ & $\mathbf{+ 2 0 . 5}$ \\
\hline 1. Dairy & 142 & 23,3 & 186 & 25,3 & +44 & +31.0 \\
\hline 2. Land cultivation and harvesting & 146 & 23,9 & 162 & 22,0 & +16 & +11.0 \\
\hline 3. Meat & 51 & 8,4 & 35 & 4,8 & -16 & -31.4 \\
\hline 4. Fruits and vegetables & 79 & 13,0 & 113 & 15,4 & +34 & +43.0 \\
\hline 5. Cereals & 40 & 6,6 & 41 & 5,6 & +1 & +2.5 \\
\hline 6. Provision of other services & 152 & 24,9 & 198 & 26,9 & +46 & +30.3 \\
\hline
\end{tabular}

*Authors' calculations using data The Cabinet of Ministers of Ukraine [7];

** As of January 1, 2018; *** As of July 19, 2019.

It should be noted that state support was provided to dairy and fruit and berry service cooperatives for the purchase of equipment for storage and processing of agricultural products (worth over UAH 8.5 million), which in some way stimulated the growth of their number in Ukraine [7]. This is an example of the introduction of public-private partnership for targeted support of multifunctional service cooperatives in a particular area of activity. In Ukraine, about $25 \%$ of the total number of agricultural cooperatives are multifunctional, combining several activities and focused on processing raw materials, which ensures their presence in the processing chain of the market chain and the possibility of increasing value added by producing and selling high quality processing products and environmental safety.

In Ukraine, the formation of agri-food chains cooperative type can not only overcome the economic alienation of individual farms, but also play an important role in overcoming the poverty of the rural population and sustainable development of rural areas. Studies have shown that agricultural service cooperatives perform 4 main functions [10, p. 17]:

1) social;

2) support for small businesses;

3) village-preserving;

4) unifying.

In the light of the concept of sustainable development, the importance of the last two functions for the balanced development of rural areas is increasing.

The social function of agrarian cooperation is realized by creating additional jobs in rural areas, reducing unemployment and migration of the rural population, increasing the income of individual farms. The FAO estimates that 1 billion people are members of cooperatives around the world, which has created more than 100 million jobs [15]. In Ukraine, the agricultural sector employs almost $18 \%$ (2,9 million people) working in economics, of which more than $68 \%$ are individuals - members of private farms. At the same time, the level of wages employed in the agricultural sector is $15 \%$ lower than the average level in the economy. The existing problem of low incomes of private farms can be solved by combining them into service cooperatives and organizing efficient agri-food chains of cooperative type.

Despite the growing trend in the number of agricultural cooperatives (see Table 5), in Ukraine the process of forming cooperative chains of the agricultural market is at an early stage. Only $1 \%$ of agricultural products are sold through the cooperative market chain, while in developed countries $-50-90 \%$. In our opinion, the main reasons hindering the development of agrarian cooperation in Ukraine include the following:

- imperfection of the institutional environment of cooperation;

- lack of a clear organizational and legal mechanism of interaction between the state and agrarian cooperatives; 
- low level of resource provision for the implementation of programs to support agricultural cooperation at various levels;

- the initial stage of formation of informal institutions of cooperation, lack of trust in cooperation in rural areas;

- low level of information support and cooperative education;

- inconsistency of activities of state and profile institutions in the field of promoting the development of agrarian cooperation;

- weakness of information connections and interactions of Ukrainian and international profile institutions of cooperation;

- low level of capitalization of cooperative enterprises.

The formation of cooperative chains of the agricultural market of Ukraine should be carried out through the interaction of the state, agricultural producers, scientists, relevant institutions and other stakeholders, in particular, local communities interested in the development of agricultural cooperation in rural areas. At the initial stage, the leading role in the development of cooperative market chains belongs to the state. In our opinion, the regulation of the formation of cooperative agri-food chains should be carried out in two strategic areas:

1) stimulating the creation of a network of multifunctional cooperatives;

2) support for the development of wholesale markets for agricultural products (hereinafter - WMAP) in the regions of Ukraine.

At the present stage, the main measures of regulatory influence of the state should be aimed at targeted support for multifunctional cooperatives, which combine several activities and focus on the processing of raw materials, thus forming an effective cooperative logistics chain. In it, due to the leveling of intermediary links and parity interactions between the subjects, a fairer distribution of value added between the links and optimization of the price of goods is achieved.

The model of development of the cooperative value chain will be considered on the example of the market of fruit and vegetable products (Fig. 1). The existing chain of this market in Ukraine is inefficient due to the presence of several intermediary links and the rejection of individual producers from the links of storage and marketing. Instead, the proposed cooperative chain provides for a fairer distribution of value added among its members on a parity basis. The effective functioning of the cooperative chain is achieved through the establishment of parity relations between the participants both within the chain and outside. Relationships of interaction (internal and external) are a form of introduction of economic interests of participants in market chains.

The formation of competitive cooperative chains of the market of fruit and vegetable products will allow their subjects to effectively interact with existing chains of corporate or intermediary type on the basis of economic partnership. Part of the products produced by multifunctional cooperatives can be transferred for storage, completion, processing or sale to the subjects of existing chains on a parity basis (see Fig. 1). Cooperatives can sell the rest of their products through the network of WMAPs and their branded stores.

In our opinion, the integration of the logistics center in the form of WMAP in the structure of the cooperative market chain will significantly strengthen its competitiveness and allow to gradually build a direct (without intermediaries) sales channel, reduce market dependence and increase export flows of products with high added value.

The main measures of state support for the establishment and operation of cooperative agri-food chains in Ukraine are as follows:

- compensation of equipment costs for multifunctional agricultural cooperatives;

- soft loans for the construction of fruit and vegetable storages, cooperative elevators and dairy farms;

- support for the creation of WMAP on the basis of public-private partnership, the allocation of land for their construction;

- informational and institutional support of the processes of cooperation and infrastructural development of the market;

- state support for producers of raw materials (in the form of subsidies and tax benefits);

- implementation of the strategy of import substitution and development of foreign markets for processed products with high added value;

- cooperation of state and profile institutions, as well as international institutions in the field of promoting the development of agrarian cooperation;

- intensification of agricultural advisory services;

- formation of regional centers of cooperation, staffing of the cooperative movement; 
- involvement of state and profile institutions in the process of forming information links between the participants of the cooperation;

- involvement of territorial communities in the cooperative movement.

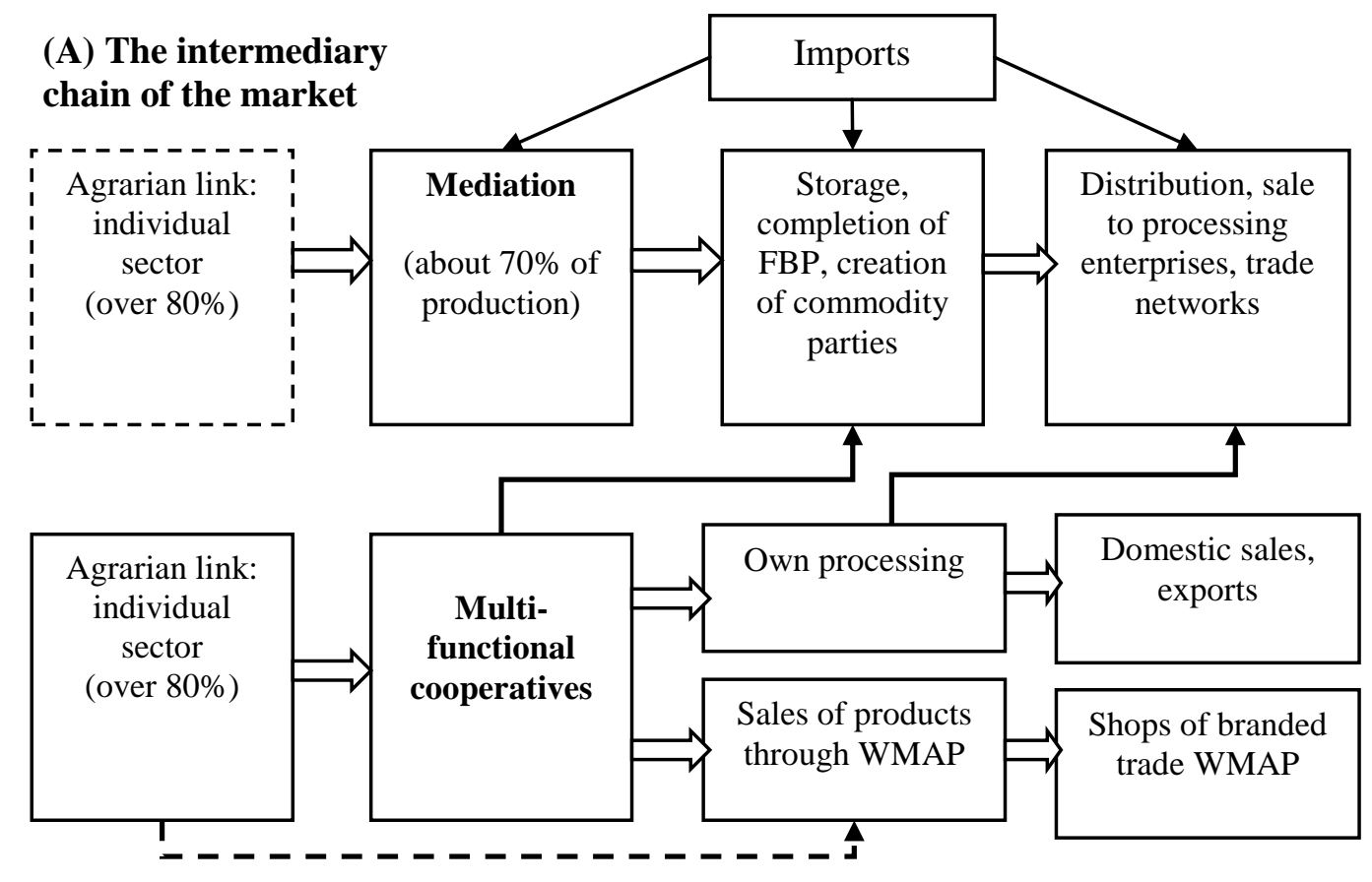

(B) Cooperative market chain

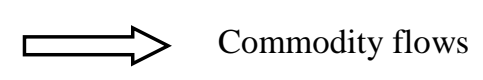

Parity interactions between market chains of different types

Figure 1 . The structure of intermediary and cooperative chains of the market of fruit and vegetable products in Ukraine [author's development]

The implementation of these measures of state support will stimulate the process of forming cooperative agri-food chains, which, in turn, will increase employment, income and living standards of the rural population, reduce migration, sustainable development of rural areas.

Conclusions and perspectives of further research. The chain approach to the study of the agricultural market of Ukraine identifies as a priority issue of access of small and medium-sized producers to the profitable links of the chains, parity interactions and objective distribution of value added in market chains. Empirical studies have shown a tendency to redistribute value added in favor of large corporations and intermediaries. At the same time, the subjects of the individual sector of the agricultural market, ensuring social, environmental and food security, remain excluded from the profitable links, and the integration of such producers into existing corporate chains is accompanied by loss of added value, which should become a resource for their sustainable reproductive development.

Taking into account the world experience, the expediency of creation of cooperative agro-food chains in Ukraine is substantiated, which include multifunctional cooperatives, a logistics center (in the form of WMAP) and branded retail stores. The implementation of the proposed state support measures is focused on ensuring the competitiveness of cooperative market chains and their ability to interact on a parity basis with corporate and intermediary chains. The development of agrarian cooperation in Ukraine and the formation of a network of cooperative market chains will allow to increase the efficiency of small-scale agricultural production, employment and welfare of the rural population, to introduce ecologically safe methods of land use, which together will contribute to the sustainable development of rural areas.

The scientific novelty of the study is to substantiate the scientific and applied principles of forming effective cooperative chains of the agricultural market for a more objective redistribution of value added between the subjects of such chains, overcoming structural and price imbalances in the market.

Prospects for further research are to develop methodological support to assess the effectiveness of cooperative chains of commodity markets, including agricultural market of Ukraine. 


\section{ЛIТЕРАТУРА}

1. Буркинський Б.В. Методологічні засади формування ефективної логістики товарних ринків: монографія / Б. В. Буркинський, В.М. Лисюк, М.Л. Тараканов та ін. - Одеса: ІПРЕЕД НАН України, 2020. $-200 \mathrm{c}$.

2. Бородіна О. М. Інтеграція дрібних сільськогосподарських виробників до агропродовольчих ланцюгів доданої вартості: методологічні підходи та емпіричні дослідження / О.М. Бородіна // Економіка і прогнозування. - 2014. - № 2. - С. 73-83.

3. Ciesielski M. Zarzadzanie lancuchami dostaw / M.Ciesielski, J. Dlugosz, K. Fuks etc.; Pod red. naukowa M. Ciesielskiego. Warszava: PWE, 211. $-350 \mathrm{p}$.

4. Winkels, Heinz-Michael (2000). Die logistische Kette. Retrieved 11.01.2021 from http://www.fhdo-winkels.de/Logistikmanagement.

5. Малік М.Й. Проблемні питання розвитку кооперації та інтеграційних відносин в АПК / М.Й. Малік, Ю.Я. Лузан // Економіка АПК. - 2010. - № 3. - С. 3-9.

6. Sakovska, O.M. (2020). Agricultural cooperation: experience of foreign countries for Ukraine / O.M. Sakovska // Baltic Journal of Economic Studies. - 6 (1). - P.118-124. https://doi.org/10.30525/22560742/2020-6-1-118-124.

7. Шеремета В. В Україні зростає кількість обслуговуючих кооперативів. Урядовий портал. URL : https://www.kmu.gov.ua/ua/news/v-ukrayini-zrostaye-kilkist-obslugovuyuchih-kooperativiv-viktorsheremeta/.

8. Andryeyeva N.M. Economic-ecological vector of transformation of the agroindustrial complex of Ukraine according to Europian Standard / N.M. Andryeyeva, G.Y.Karpenko // East European Scientific Journal. - 2016. - 3 (7) . - P.5-10.

9. Hetman O. Eco - innovations under conditions of glocalization of economic and sustainable development of the regional economy / O. Hetman, O. Iermakova, O. Laiko O. etc. // Ekonomia $\mathrm{i}$ Środowisko. - 2019. - 4 (71). - P. 69-82. https://doi.org/10.34659/2019/4/49.

10. Нікішина О.В. Формування та розвиток регіональних обслуговуючих кооперативів зернового ринку: інтеграційний підхід : монографія / О.В. Нікішина, Н.О. Бібікова. - Одеса : ІПРЕЕД НАН України, 2018. - 230 с.

11. Нікішина О.В. Формування й регулювання ефективних логістичних ланцюгів плодовоягідного ринку України / О.В. Нікішина, Т.П. Лозова, М.Л. Тараканов // European journal of economics and management. $-2020 .-1(6)$. - C. 67-76.

12. Сільське господарство України за 2019 рік: статистичний збірник / Відп. за випуск О.М. Прокопенко. Київ: Державна служба статистики України, 2020. -230 с.

13. Офіційний сайт Державної служби статистики України. URL : http://www.ukrstat.gov.ua/.

14. Нікішина О.В. Інклюзивний підхід до формування логістичних ланцюгів аграрного ринку України / О.В. Нікішина // Економіка АПК. - 2020. - № 1. - С. 46-55. https://doi.org/10.32317/22211055.202001046

15. Agricultural Cooperatives Key to Feeding the World (2012). Rome FAO. URL: http://www.fao.org/fileadmin/templates/getinvolved/images/WFD2012_leaflet_en_low.pdf.

16. Статистичний щорічник України за 2019 рік / За ред. I.Є. Вернера. Київ: Державна служба статистики України. 2020. - 465 с.

\section{REFERENCES}

1. Burkynskyi, B.V., Lysiuk, V.M. \& Tarakanov, M.L. etc. (2020). Metodolohichni zasady formuvannia efektyvnoi lohistyky tovarnykh rynkiv: monohrafiia [Methodological bases of formation of effective logistics of commodity markets]. Odesa: IPREED NAN Ukrainy [in Ukrainian].

2. Borodina, O.M. (2014). Intehratsiia dribnykh silskohospodarskykh vyrobnykiv do ahroprodovolchykh lantsiuhiv dodanoi vartosti: metodolohichni pidkhody ta empirychni doslidzhennia [Integration of smallholder farmers into value-added agri-food chains: methodological approaches and empirical research]. Ekonomika i prohnozuvannia. - Economics and forecasting, 2, 73-83 [in Ukrainian].

3. Ciesielski, M., Dlugosz, J., Fuks, K. etc. (2011). Zarzadzanie lancuchami dostaw. Pod red. naukowa M. Ciesielskiego. Warszava: PWE [in Polish].

4. Winkels, Heinz-Michael (2000). Die logistische Kette. Retrieved 11.01.2021 from http://www.fhdowinkels.de/Logistikmanagement [in English]. 
5. Malik M.I., Luzan Yu.Ia. (2010). Problemni pytannia rozvytku kooperatsii ta intehratsiinykh vidnosyn $\mathrm{v}$ APK. [Problematic issues of cooperation and integration relations in the agro-industrial complex]. Ekonomika APK. - Economics of agro-industrial complex, 3, 3-9 [in Ukrainian].

6. Sakovska, O.M. (2020). Agricultural cooperation: experience of foreign countries for Ukraine. Baltic Journal of Economic Studies, 6 (1), 118-124. https://doi.org/10.30525/2256-0742/2020-6-1-118-124 [in English].

7. Sheremeta, V. (2019). In Ukraine, the number of service cooperatives is growing. Retrieved 11.01.2021 from https://www.kmu.gov.ua/ua/news/v-ukrayini-zrostaye-kilkist-obslugovuyuchihkooperativiv-viktor-sheremeta [in Ukrainian].

8. Andryeyeva, N.M., Karpenko, G.Y. (2016). Economic-ecological vector of transformation of the agroindustrial complex of Ukraine according to Europian Standard. East European Scientific Journal, 3 (7), 5-10 [in English].

9. Hetman, O., Iermakova, O. \& Laiko O. etc. (2019). Eco - innovations under conditions of glocalization of economic and sustainable development of the regional economy. Ekonomia $i$ Środowisko, 4 (71), 69-82. https://doi.org/10.34659/2019/4/49 [in English].

10. Nikishyna, O.V., Bibikova, N.O. (2018). Formuvannia ta rozvytok rehionalnykh obsluhovuiuchykh kooperatyviv zernovoho rynku: intehratsiinyi pidkhid: monohrafiia. [Formation and development of regional service cooperatives of the grain market: an integration approach: monograph]. Odesa: IPREED NAN Ukrainy [in Ukrainian].

11. Nikishyna, O., Lozova, T. \&Tarakanov, M. (2020). Formuvannia y rehuliuvannia efektyvnykh lohistychnykh lantsiuhiv plodovo-yahidnoho rynku Ukrainy [Formation and regulation of efficient logistics chains of the fruit and berry market of Ukraine]. European journal of economics and management, 1(6), 6776. [in Ukrainian].

12. Silske hospodarstvo Ukrainy za 2019 rik: statystychnyi zbirnyk (2020). [Agriculture of Ukraine for 2019: statistical compilation]. Kyiv: Derzhavna sluzhba statystyky Ukrainy [in Ukrainian].

13. Ofitsiinyi sait Derzhavnoi sluzhby statystyky Ukrainy [Official site of the State Statistics Service of Ukraine]. Retrieved 11.01.2021 from http://www.ukrstat.gov.ua/ [in Ukrainian].

14. Nikishyna, O.V. (2020). Inkliuzyvnyi pidkhid do formuvannia lohistychnykh lantsiuhiv ahrarnoho rynku Ukrainy [An inclusive approach to the formation of logistics chains in the agricultural market of Ukraine]. Ekonomika APK. - Economics of agro-industrial complex, 1, 46-55. https://doi.org/10.32317/2221-1055.202001046 [in Ukrainian].

15. Agricultural Cooperatives Key to Feeding the World (2012). Rome FAO. Retrieved 11.01.2021 from http://www.fao.org/fileadmin/templates/getinvolved/images/WFD2012_leaflet_en_low.pdf. [in English].

16. Statystychnyi shchorichnyk Ukrainy za 2019 rik (2020) [Statistical Yearbook of Ukraine for 2019]. Kyiv: Derzhavna sluzhba statystyky Ukrainy [in Ukrainian]. 